\title{
Macrobrachium rosenbergii nodavirus infection in M. rosenbergii (de Man) with white tail disease cultured in Taiwan
}

\author{
C S Wang ${ }^{1}$, J S Chang ${ }^{1}$, C M Wen ${ }^{1}$, H H Shih ${ }^{2}$ and S N Chen ${ }^{3}$ \\ 1 Department of Life Sciences, National University of Kaohsiung, Kaohsiung, Taiwan \\ 2 Department of Life Science, National Taiwan University, Taipei, Taiwan \\ 3 Institute of Fisheries Science, National Taiwan University, Taipei, Taiwan
}

\begin{abstract}
White tail disease (WTD) is a serious problem in Macrobrachium rosenbergii hatcheries and nursery ponds in Asia. The causative agents have been identified as $M$. rosenbergii nodavirus $(M r \mathrm{NV})$ and its associated extra small virus. This is the first report demonstrating $M r \mathrm{NV}$ virus in $M$. rosenbergii displaying WTD signs in Taiwan by reverse transcriptase-polymerase chain reaction (RT-PCR). Amplified fragments of 850 and 425 bp for RNA-1 and RNA-2 of $M r \mathrm{NV}$, respectively, were obtained by RT-PCR. RT-PCR products of about 850 and 1121 bp for RNA-1 and RNA-2 of $M r N V$ were also obtained using different primer pairs. The amplicons were individually cloned into pGEM-T vector and sequenced. Using this recombinant plasmid of $M r \mathrm{NV}$ RNA-2 as DNA template, the non-radioactive DNA probes were prepared by PCR amplification with DIG-11-dUTP. The probes were used to successfully detect $M r \mathrm{NV}$ infection in the striated muscle tissues of WTDdiseased prawns using in situ hybridization. The 1121 bp genomic fragment of RNA-2 of $M r N V$ consisted of a unique open reading frame with 1116 nucleotides, and it encoded a structural protein with 371 amino acids. The nucleotide sequence of the partial genome of $M r \mathrm{NV}$ RNA-2 revealed a $97 \%$ identity with an Indian isolate. A phylogenetic tree constructed using the nucleotide sequence of the viral capsid gene from insect and
\end{abstract}

Correspondence C S Wang, Department of Life Sciences, National University of Kaohsiung, Kaohsiung 811, Taiwan (e-mail: cswang@nuk.edu.tw) fish nodaviruses revealed that the $M r \mathrm{NV}$ Taiwan isolate could be interpreted as a new genus within the family Nodaviridae. However, its position showed more affinity with Alphanodavirus than with Betanodavirus. The study confirmed the presence of $M r \mathrm{NV}$ infection in freshwater prawns cultured in Taiwan suffering from WTD.

Keywords: in situ hybridization, Macrobrachium rosenbergii, Macrobrachium rosenbergii nodavirus, reverse transcriptase-polymerase chain reaction, white tail disease.

\section{Introduction}

Viral diseases are a major problem for crustacean aquaculture worldwide. The giant freshwater prawn, Macrobrachium rosenbergii (de Man), is an economically important crustacean in Taiwan. A new viral disease designated as white tail disease (WTD) has been observed in freshwater prawn hatcheries and nursery ponds since 1992, causing high mortalities and huge economic losses. The affected prawns exhibit white, opaque muscle in the abdominal segments, commonly accompanied by progressive reduction in feeding and swimming. Mortalities may reach between $50 \%$ and $70 \%$ within 2 weeks after transfer of post-larvae (PL) to grow-out ponds (Tung, Wang \& Chen 1999). WTD has recently been reported in the French West Indies (Arcier, Herman, Lightner, Redman, Mari \& Bonami 1999), People's Republic of China (Qian, Shi, Zhang, Cao, Liu, Li, Xie, Cambournac \& Bonami 2003), India (Sahul Hameed, Yoganandhan, Sri Widada \& Bonami 2004; Shekhar,
(C) 2008 The Authors. Journal compilation (C) 2008

Blackwell Publishing Ltd 
Azad \& Jithendran 2006) and Thailand (Yoganandhan, Leartvibhas, Sriwongpuk \& Limsuwan 2006).

The causative agents of WTD have been identified as Macrobrachium rosenbergii nodavirus $(M r \mathrm{NV})$ associated with extra small virus (XSV) (Qian et al. 2003). $M r N V$ is a small icosahedral non-enveloped virus, $26-27 \mathrm{~nm}$ in diameter, observed in the cytoplasm of connective tissue cells in infected prawns. The viral genome is composed of two fragments of linear, singlestranded, positive-sense RNAs (RNA-1 and RNA-2), of about 2.9 and $1.3 \mathrm{~kb}$, respectively. The viral capsid contains a single polypeptide of $43 \mathrm{kDa}$ (Bonami, Shi, Qian \& Sri Widada 2005). The XSV virus is icosahedral in shape and $15 \mathrm{~nm}$ in diameter. Its genome consists of a linear, singlestranded RNA of 796 nucleotides, encoding a single structural protein of $17 \mathrm{kDa}(\mathrm{CP}-17)$ (Sri Widada \& Bonami 2004). Because the clinical signs of WTD are not specific, other methods are required to screen for the aetiological agents. A number of diagnostic methods have been developed for the detection of $M r \mathrm{NV}$, including dotblot hybridization, in situ hybridization, reverse transcriptase-polymerase chain reaction (RT-PCR) and ELISA (Romestand \& Bonami 2003; Sri Widada, Durand, Cambournac, Qian, Shi, Dejonghe, Richard \& Bonami 2003). Dot-blot hybridization and RT-PCR have also been developed for the detection of XSV (Sri Widada, Richard, Shi, Qian \& Bonami 2004). A single-tube, one-step multiplex RT-PCR has been developed for $M r \mathrm{NV}$ and XSV (Yoganandhan, Sri Widada, Bonami \& Sahul Hameed 2005).

In a previous study, XSV was detected in WTD-affected $M$. rosenbergii in Taiwan (Wang, Chang, Shi \& Chen 2007). The present study is the first confirming $M r \mathrm{NV}$ infection by RT-PCR in diseased freshwater prawns showing clinical signs of WTD. The RT-PCR amplified products of $M r \mathrm{NV}$ were further cloned and sequenced. The Digoxigenin DNA probes for $M r \mathrm{NV}$ were labelled by PCR amplification using the recombinant plasmid as template. Using in situ hybridization, the results verified $M r \mathrm{NV}$ infection in the white muscle tissue of WTDdiseased prawns. The phylogenetic relationships of $M r \mathrm{NV}$ with other nodavirus isolates were investigated by comparing the nucleotide sequences of viral coat protein.

\section{Materials and methods}

\section{Collection of infected post-larvae}

Infected PL of $M$. rosenbergii with WTD were collected from affected hatcheries located in $\mathrm{Ka}$ ohsiung and Pington in southern Taiwan. More than 30 diseased giant freshwater prawn samples, each consisting of 10-30 individuals, were collected. Healthy animals were obtained from a hatchery with no record of WTD. The PL were washed in sterile distilled water and stored at $-20{ }^{\circ} \mathrm{C}$ before processing. Some samples were placed in Davidson's fixative for in situ hybridization.

\section{Total RNA extraction}

Total RNA was extracted using TRIzol ${ }^{\mathrm{TM}}$ reagent (Invitrogen, Carlsbad, CA, USA) according to the procedure described by Wang et al. (2007). Total RNA was dissolved in $50 \mu \mathrm{L}$ of diethyl pyrocarbonate-treated water and stored at $-70{ }^{\circ} \mathrm{C}$.

\section{RT-PCR for $M r N V$}

Reverse transcriptase-polymerase chain reaction was performed using a Reverse-iT ${ }^{\mathrm{TM}}$ one-step RT-PCR kit (ABgene, Surrey, UK), allowing reverse transcription (RT) and amplification to be carried out in a single reaction tube. The details of primer sequences and amplified product sizes are given in Table 1 . One primer pair (pair 1) designed from the RNA-1 sequence of $M r \mathrm{NV}$ and another primer pair (pair 3) specific to the RNA-2 sequence of $M r N V$ were tested separately for the detection of $M r \mathrm{NV}$ infection. The reaction was performed in $50 \mu \mathrm{L}$ of RT-PCR buffer containing 10 pmol of each primer and RNA template, using the following steps: reverse transcription at $52{ }^{\circ} \mathrm{C}$ for $1 \mathrm{~h}$; denaturation at $94^{\circ} \mathrm{C}$ for $2 \mathrm{~min}$ followed by 35 cycles of denaturation at $94^{\circ} \mathrm{C}$ for $40 \mathrm{~s}$; annealing at $55^{\circ} \mathrm{C}$ for $40 \mathrm{~s}$ and elongation at $72{ }^{\circ} \mathrm{C}$ for $1 \mathrm{~min}$, ending with an additional elongation step of $10 \mathrm{~min}$ at $72^{\circ} \mathrm{C}$. The amplified product was analysed by electrophoresis on a $1.5 \%$ agarose gel.

\section{Cloning}

In order to determine the homology of nucleotide sequence of $M r \mathrm{NV}$ isolated from Taiwan with other nodavirus isolates, RT-PCR was carried out with a different primer pair (pair 2) as well primer pair 1 used for the amplification of RNA-1. The RT-PCR
(C) 2008 The Authors. Journal compilation (C) 2008 Blackwell Publishing Ltd 
Table 1 Pairs of primers used in reverse transcriptase-polymerase chain reaction for the amplification of Macrobrachium rosenbergii nodavirus $(M r \mathrm{NV})$ RNA

\begin{tabular}{|c|c|c|c|c|c|}
\hline Pair & Name & Sequence & Size (bp) & Orientation & Reference \\
\hline 1 (RNA-1) & $\begin{array}{l}\text { 1A775 } \\
1 \mathrm{~B} 690\end{array}$ & $\begin{array}{l}\text { CCACGTTCTTAGTGGATCCT } \\
\text { CGTCCGCCTGGTAGTTCC }\end{array}$ & 850 & $\begin{array}{l}\text { Upstream primer } \\
\text { Downstream primer }\end{array}$ & Sri Widada et al. (2003) \\
\hline 2 (RNA-2) & $\begin{array}{l}\text { CapS } \\
\text { CapC }\end{array}$ & $\begin{array}{l}\text { ATGGCTAGAGGTAAACAAAATTC } \\
\text { ACAACCTAATTATTGCCGAC }\end{array}$ & 1121 & $\begin{array}{l}\text { Upstream primer } \\
\text { Downstream primer }\end{array}$ & Sri Widada et al. (2003) \\
\hline 3 (RNA-2) & $\begin{array}{l}\text { MrNV2aF } \\
M r N V 2 a R\end{array}$ & $\begin{array}{l}\text { GCGTTATAGATGGCACAAGG } \\
\text { AGCTGTGAAACTTCAACTGG }\end{array}$ & 425 & $\begin{array}{l}\text { Upstream primer } \\
\text { Downstream primer }\end{array}$ & Sahul Hameed et al. (2004) \\
\hline
\end{tabular}

The primer pair specific to RNA-1 or RNA-2 of $M r N V$ is given in parentheses.

was performed under the same conditions as described previously; the amplified products were separately extracted from agarose gels, and purified using a PCR clean-up system (Promega Corporation, Madison, WI, USA). The DNA fragments were individually ligated into pGEM-T Easy Vector (Promega Corporation) and transformed into Escherichia coli $\mathrm{DH}-5 \alpha$. The clones were designated as DMNV-1 and DMNV-2 for RNA-1 and RNA-2 of $M r \mathrm{NV}$, respectively. The recombinant plasmid DNA from the two clones were separately extracted, and automatic sequencing was performed commercially (Protech Technology Enterprise Co., Ltd, Tapei, Taiwan).

\section{DNA probe labelling}

The DIG-labelled probe for RNA-2 of $M r \mathrm{NV}$ was generated with a PCR DIG Probe Synthesis Kit (Roche Molecular Biochemicals, Mannheim, Germany) following the manufacturer's instructions with slight modifications. Briefly, a $0.5-\mathrm{mL}$ reaction tube was added to the following final concentration of reagents: $1 \mathrm{X}$ PCR buffer $(10 \mathrm{~mm}$ Tris- $\mathrm{HCl}$, $50 \mathrm{~mm} \mathrm{KCl}, 2.5 \mathrm{~mm} \mathrm{MgCl}_{2}$ ), $200 \mu$ м PCR DIG probe synthesis mix, $0.5 \mu \mathrm{m}$ of primer $M r \mathrm{NV} 2 \mathrm{aF}$ and $M r N V 2 a F, 1$ unit Taq DNA polymerase, recombinant plasmid template derived from the clone DMNV-2 and distilled water to a final volume of $50 \mu \mathrm{L}$. The PCR was carried out in a thermal cycler (Thermo Hybaid, Needham Heights, MA, USA) with 35 cycles of $94{ }^{\circ} \mathrm{C}$ for $40 \mathrm{~s}, 55^{\circ} \mathrm{C}$ for $40 \mathrm{~s}$ and $72{ }^{\circ} \mathrm{C}$ for $1 \mathrm{~min}$. The resulting DIG-labelled DNA probe was extracted from agarose gel and purified using a PCR clean-up system (Promega Corporation).

\section{In situ hybridization}

(C) 2008 The Authors. Journal compilation (C) 2008

Blackwell Publishing Ltd
All histological processing and staining followed standard procedures, as described by Bell \&
Lightner (1988). Sections, 5-7 $\mu \mathrm{m}$ thick, were used for in situ hybridization using DIG-labelled probe according to the manufacturer's manual (Roche Molecular Biochemicals). The sections were deparaffined and rehydrated in a series of graded ethanol, followed by digestion with proteinase $\mathrm{K}\left(100 \mu \mathrm{g} \mathrm{mL}^{-1}\right)$ and then fixed in cold $4 \%$ formaldehyde. The sections were heated to $95^{\circ} \mathrm{C}$ for $10 \mathrm{~min}$ and allowed to hybridize for $12 \mathrm{~h}$ at $42{ }^{\circ} \mathrm{C}$ in the probe hybridization solution containing $50 \%$ formamide, $1 \mu \mathrm{g} \mathrm{mL}^{-1}$ DIGlabelled probe, $0.2 \mathrm{mg} \mathrm{mL}^{-1}$ sonicated salmon sperm DNA and 5\% dextran sulphate, and $4 \mathrm{X}$ SSC $(0.6 \mathrm{~m}$ sodium chloride, $60 \mathrm{~mm}$ sodium citrate, $\mathrm{pH}$ 7.0). The detection was performed using an alkaline phosphatase-conjugated antiDIG antibody and substrate solution (nitroblue tetrazolium and bromo-4-chloro-3-indolyphosphate). After counterstaining with $0.1 \%$ eosin $Y$, the sections were dehydrated and mounted with Entellan (Merck KGaA, Darmstadt, Germany) and then examined under bright field microscopy (Olympus BX51, Tokyo, Japan).

\section{Sequence analysis}

Nucleotide sequence analysis for the partial genome of RNA-2 of $M r \mathrm{NV}$ was performed with other nodavirus isolates including Indian $\mathrm{MrNV}$ (AY222840), black beetle virus (NC002037), Boolarra virus (NC004145), greasy grouper nervous necrosis virus (AF318942), Nodamura virus (AF174534), red spotted grouper nervous necrosis virus (RGNNV) (NC008041), Pariacoto virus (NC003692) and striped jack nervous necrosis virus (SJNNV) (AB056572) using BLAST (Altschul, Madden, Schäffer, Zhang, Zhang, Miller \& Lipman 1997) and Clustal w (Thompson, Higgins \& Gibson 1994). The phylogenetic analysis was performed using the neighbour-joining method

(Saitou \& Nei 1987). 


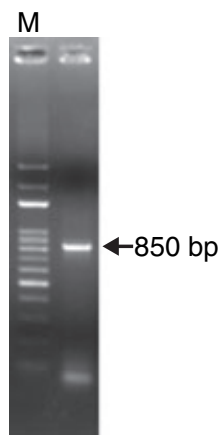

(a)

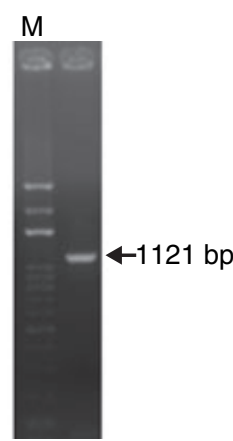

(b)

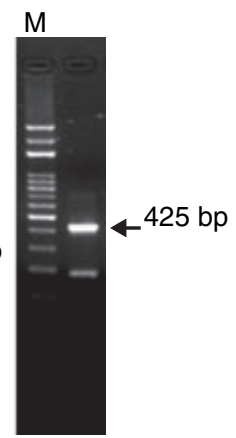

(c)
Figure 1 Agarose gels showing reverse transcriptase-polymerase chain reaction products of Macrobrachium rosenbergii nodavirus $(M r \mathrm{NV})$ extracted from post-larvae of white tail disease infected $M$. rosenbergii using different primer pairs. (a) $850 \mathrm{bp}$ amplified product using primer pair 1 for RNA-1 of $M r \mathrm{NV}$; (b) $1121 \mathrm{bp}$ amplified product using primer pair 2 for RNA-2 of $M r N V$; (c) 425 bp amplified product using primer pair 3 for RNA-2 of MrNV. M: 100-bp DNA ladder marker.

\section{Results}

Diseased 24 to 32 day old post-larvae with whitish muscle were collected from different hatcheries in southern Taiwan. All WTD-affected cases were confirmed with $M r \mathrm{NV}$ virus infection by RT-PCR analysis. As shown in Fig. 1a \& c, the 850 and $425 \mathrm{bp}$ amplified products were obtained using primer pairs 1 and 3 specific to the genome of the RNA-1 and RNA-2 of $M r \mathrm{NV}$ virus, respectively. Samples obtained from the unaffected hatchery were negative for $M r \mathrm{NV}$. Using different primers (pairs 1 and 2), 850 and $1121 \mathrm{bp}$ amplified products were obtained by RT-PCR (Fig. 1a \& b). The nucleotide sequence for the partial viral genome have been deposited in GenBank (GenBank accession no. DQ521574 for RNA-1 of $M r \mathrm{NV}$; DQ521575 for RNA-2 of $M r \mathrm{NV}$ ). The DIG DNA probes for $M r \mathrm{NV}$ were labelled by PCR amplification using the recombinant plasmid as template. Using in situ hybridization, the results showed that the $M r \mathrm{NV}$ genome could be successfully detected in the striated muscle of WTD-affected prawns. Positive reactions were recognized by a blue purple precipitate in the myofibrils but not in the nuclei of the muscle tissues (Fig. 2). However, no labelling was observed in the gill, hepatopancreas, nerve cord or stomach. No $M r \mathrm{NV}$ infection was found in the muscle tissue of healthy prawns (C) 2008 The Authors. Journal compilation using in situ hybridization.
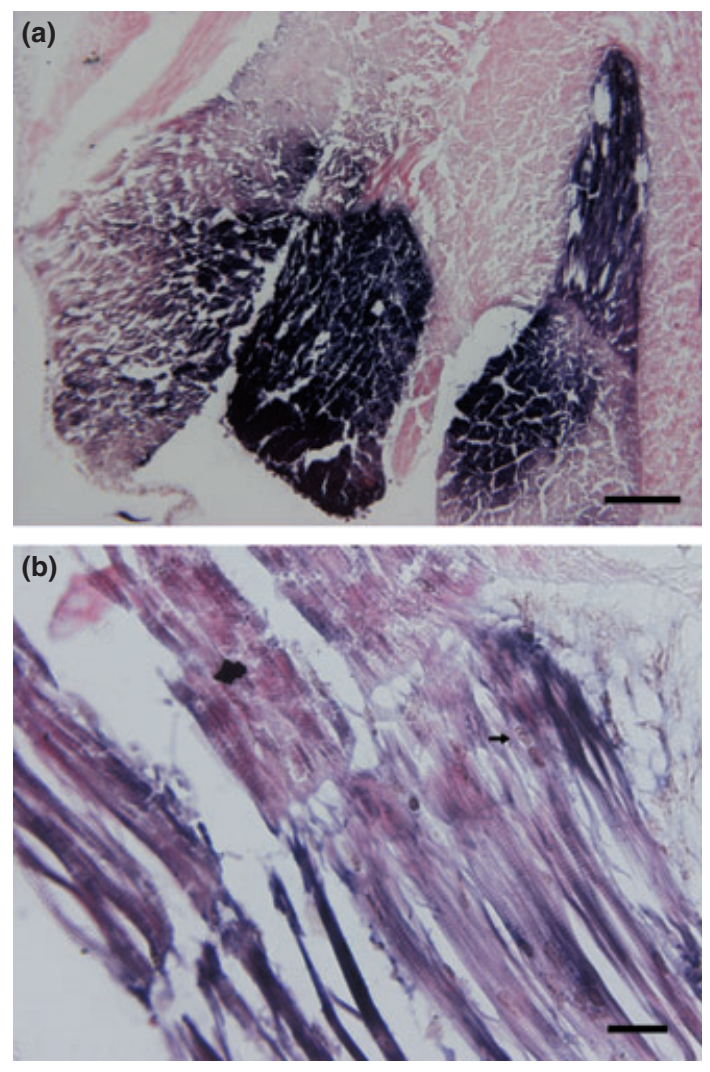

Figure 2 In situ hybridization of $M$. rosenbergii nodavirus $(M r \mathrm{NV})$-infected $M$. rosenbergii with white tail disease using a DIG-labelled probe. (a) The striated muscle of an $M r N V$ infected prawn showing a positive reaction in the affected muscle tissue (eosin Y as counterstain; bar $=100 \mu \mathrm{m}$ ). (b) A higher magnification of the necrotic muscle showing dark purple colouration in the myofibrils; the nuclei are negative (arrow) (eosin $\mathrm{Y}$ as counterstain; bar $=25 \mu \mathrm{m})$.

The nucleotide and deduced amino acid sequences of $M r$ NV RNA-2 partial genome are shown in Fig. 3. It contained a unique open reading frame with 1116 nucleotides and encoded a structural protein with 371 amino acids. A comparison of the sequence of the RNA-2 of the MrNV Taiwan isolate showed a 97\% identity BLAST analysis with the $M r \mathrm{NV}$ Indian isolate (AY222840). In addition, the deduced amino acid sequences of the $M r \mathrm{NV}$ Taiwan isolate showed strong homology with the Indian isolate with five deduced amino acid substitutions at positions 84 $(\mathrm{T} \rightarrow \mathrm{I}), 248(\mathrm{~T} \rightarrow \mathrm{S}), 291(\mathrm{~V} \rightarrow \mathrm{I}), 321(\mathrm{~F} \rightarrow \mathrm{S})$ and $333(\mathrm{~S} \rightarrow \mathrm{L})$. In order to more precisely establish the systemic position of $M r \mathrm{NV}$, a phylogenetic tree was constructed using the amino acid sequences deduced from the viral capsid gene of insect and fish nodaviruses. The results showed that the $M r \mathrm{NV}$ Taiwan isolate had more affinity with 
Figure 3 Nucleotide sequences and deduced amino acid sequences of the partial genome of Macrobrachium rosenbergii nodavirus RNA-2. The numbering for the nucleotide sequences is given on the left and the numbering for the sequences of deduced amino acid is on the right.
1 atggctagaggtaaacaaaattctaatcagattcaaaataatagtaacgcaaacggc aag $\begin{array}{lllllllllllllllllllll}M & A & R & G & K & Q & N & S & N & Q & I & Q & N & N & S & N & A & N & G & K & 20\end{array}$

60 cgccgtaagcgtaatcgaaggaatcgtaatccgcagacggttcccaactttaaccccatt $\begin{array}{lllllllllllllllllllll}\mathrm{R} & \mathrm{R} & \mathrm{K} & \mathrm{R} & \mathrm{N} & \mathrm{R} & \mathrm{R} & \mathrm{N} & \mathrm{R} & \mathrm{N} & \mathrm{P} & \mathrm{Q} & \mathrm{T} & \mathrm{V} & \mathrm{P} & \mathrm{N} & \mathrm{F} & \mathrm{N} & \mathrm{P} & \mathrm{I} & 40\end{array}$

120 gtcgcaaagccgacggttgccccacttcaaactaacattagaagtgctaggagtgac gtt $\begin{array}{lllllllllllllllllllll}\mathrm{V} & \mathrm{A} & \mathrm{K} & \mathrm{P} & \mathrm{T} & \mathrm{V} & \mathrm{A} & \mathrm{P} & \mathrm{L} & \mathrm{Q} & \mathrm{T} & \mathrm{N} & \mathrm{I} & \mathrm{R} & \mathrm{S} & \mathrm{A} & \mathrm{R} & \mathrm{S} & \mathrm{D} & \mathrm{V} & 60\end{array}$

180 aatgccatcaccgttttaaatggcagcgatttccttacaactgtcaaagtccgaggttct $\begin{array}{lllllllllllllllllllll}\mathrm{N} & \mathrm{A} & \mathrm{I} & \mathrm{T} & \mathrm{V} & \mathrm{L} & \mathrm{N} & \mathrm{G} & \mathrm{S} & \mathrm{D} & \mathrm{F} & \mathrm{L} & \mathrm{T} & \mathrm{T} & \mathrm{V} & \mathrm{K} & \mathrm{V} & \mathrm{R} & \mathrm{G} & \mathrm{S} & 80\end{array}$

240 aataacttaattgattccaagtctagaatcttggttaagcaaccaatttctgcgagt tct $\begin{array}{lllllllllllllllllllll}\mathrm{N} & \mathrm{N} & \mathrm{L} & \mathrm{I} & \mathrm{D} & \mathrm{S} & \mathrm{K} & \mathrm{S} & \mathrm{R} & \text { I } & \text { L } & \text { V } & \text { K } & \text { Q } & \text { P } & \text { I } & \text { S } & \text { A } & \text { S } & \text { S } & 100\end{array}$ 300 tttcttggtaccagaatttctggtctatcgcaattttgggagcgttatagatggcacaag $\begin{array}{lllllllllllllllllllll}\text { F } & \text { L } & G & \text { T } & \text { R } & \text { I } & \text { S } & G & \text { L } & \text { S } & \text { Q } & \text { F } & \text { W } & \text { E } & \text { R } & \text { Y } & \text { R } & \text { W } & \text { H } & \text { K } & 120\end{array}$

360 gctgcagtcagatatgttcctgcagtacccaatactttagcttgccaacttattggt tac $\begin{array}{lllllllllllllllllllll}\text { A } & \text { A } & \text { V } & \text { R } & \text { Y } & \text { V } & \text { P } & \text { A } & \text { V } & \text { P } & \text { N } & \text { T } & \text { L } & \text { A } & \text { C } & \text { Q } & \text { L } & \text { I } & \text { G } & \text { Y } & 140\end{array}$

420 atcgatacagatccactagatgaccctaacgttatcctcgatgttgatcagttacttagg $\begin{array}{lllllllllllllllllllll}\text { I } & D & \text { T } & \text { D } & \text { P } & \text { L } & \text { D } & \text { D } & \text { P } & \text { N } & \text { V } & \text { I } & \text { L } & \text { D } & \text { V } & \text { D } & \text { Q } & \text { L } & \text { L } & \text { R } & 160\end{array}$

480 caggccacgtcacaagtgggtgcgcggcagtggaatttttctgatacaacaactattcca $\begin{array}{lllllllllllllllllllll}\text { Q } & \text { A } & \text { T } & \text { S } & \text { Q } & \text { V } & G & \text { A } & R & \text { Q } & \text { W } & \text { N } & \text { F } & \text { S } & \text { D } & \text { T } & \text { T } & \text { T } & \text { I } & \text { P } & 180\end{array}$

540 ttgattgtcaggcgtgatgatcaattgtactatactggccaagataaggagaacgttcgt $\begin{array}{lllllllllllllllllllll}\text { L } & I & \text { V } & \text { R } & \text { R } & \text { D } & \text { D } & \text { Q } & \text { L } & \text { Y } & \text { Y } & \text { T } & \text { G } & \text { Q } & \text { D } & \text { K } & \text { E } & \text { N } & \text { V } & \text { R } & 200\end{array}$

600 ttctctcaacagggtgtattttacctcttgcaagtgactacactactcaatattagtggt $\begin{array}{lllllllllllllllllllll}\text { F } & \text { S } & \text { Q } & \text { Q } & \text { G } & \text { V } & \text { F } & \text { Y } & \text { L } & \text { L } & \text { Q } & \text { V } & \text { T } & \text { T } & \text { L } & \text { L } & \text { N } & \text { I } & \text { S } & \text { G } & 220\end{array}$

660 gaagccattacaaatgatttgatttcaggttcactatatttagattgggtctgtggattt $\begin{array}{lllllllllllllllllllll}\text { E } & \text { A } & \text { I } & \text { T } & \text { N } & \text { D } & \text { L } & \text { I } & \text { S } & G & \text { S } & \text { L } & \text { Y } & \text { L } & \text { D } & \text { W } & \text { V } & \text { C } & \text { G } & \text { F } & 240\end{array}$

720 tccatgccacaaattaatccttcaccagtggaagtttcacagctaacttataatgcg gat $\begin{array}{lllllllllllllllllllll}\text { S } & M & P & Q & I & N & P & S & P & V & E & V & \text { S } & Q & \text { L } & \text { T } & \text { Y } & \text { N } & \text { A } & \text { D } & 260\end{array}$

780 actattggcaattgggttccaccaacagaactcaagcaaacttatactcaagatatt act $\begin{array}{lllllllllllllllllllll}T & I & G & N & W & V & P & P & T & E & L & K & Q & T & Y & T & Q & D & \text { I } & T & 280\end{array}$

840 ggtttgaagccaaattctaaatttattattataccttatatggatagagtaagttct gaa $\begin{array}{lllllllllllllllllllll}\text { G } & \text { L } & \text { K } & \text { P } & \text { N } & \text { S } & \text { K } & \text { F } & \text { I } & \text { I } & \text { I } & \text { P } & \text { Y } & \text { M } & \text { D } & \text { R } & \text { V } & \text { S } & \text { S } & \text { E } & 300\end{array}$ 900 gtactgcagaagtgcacaattact tgtaatgaggttgacgccgttggttcaatctca tat $\begin{array}{lllllllllllllllllllll}\text { V } & \text { L } & \text { Q } & \text { K } & \text { C } & \text { T } & \text { I } & \text { T } & \text { C } & \text { N } & \text { E } & \text { V } & \text { D } & \text { A } & \text { V } & \text { G } & \text { S } & \text { I } & \text { S } & \text { Y } & 320\end{array}$ 960 tccgatactagcgctatcaaatgtgatgggtacatattatttcaggccaatagcatt ggt $\begin{array}{lllllllllllllllllllll}S & D & T & S & A & I & K & C & D & G & Y & \text { I } & \text { L } & \text { F } & \text { Q } & \text { A } & \text { N } & \text { S } & \text { I } & G & 340\end{array}$ 1020 gaagcaaccttcaccttagtgaccgattatcagggtgcggttgaccctaaccctatcag $\begin{array}{lllllllllllllllllllll}\text { E } & \text { A } & \text { T } & \text { F } & \text { T } & \text { L } & \text { V } & \text { T } & \text { D } & \text { Y } & \text { Q } & \text { G } & \text { A } & \text { V } & \text { D } & \text { P } & \text { K } & \text { P } & \text { Y } & \text { Q } & 360\end{array}$ 1080 tataggattatcagagctatcgtcggcaataattaggttgt

$\begin{array}{llllllllllll}\text { Y } & \mathrm{R} & \mathrm{I} & \mathrm{I} & \mathrm{R} & \mathrm{A} & \mathrm{I} & \mathrm{V} & \mathrm{G} & \mathrm{N} & \mathrm{N} & *\end{array}$ (c) 2008 The Authors. Journal compilation (C) 2008 Blackwell Publishing Ltd affected muscle. Non-enveloped virions with a mean size of $23 \mathrm{~nm}$ were found in the cytoplasm of infected cells in the prawns, and were tentatively named as Macrobrachium muscle virus (MMV). Although MMV was not isolated and characterized, in its morphology, cytoplasmic location and striated muscle affinity, and in the clinical gross signs displayed by infected animals, it appears very similar to $M r N V$. The present study is the first report confirming $M r \mathrm{NV}$ virus infection associated with WTD of $M$. rosenbergii cultured in Taiwan by RT-PCR and in situ hybridization. 


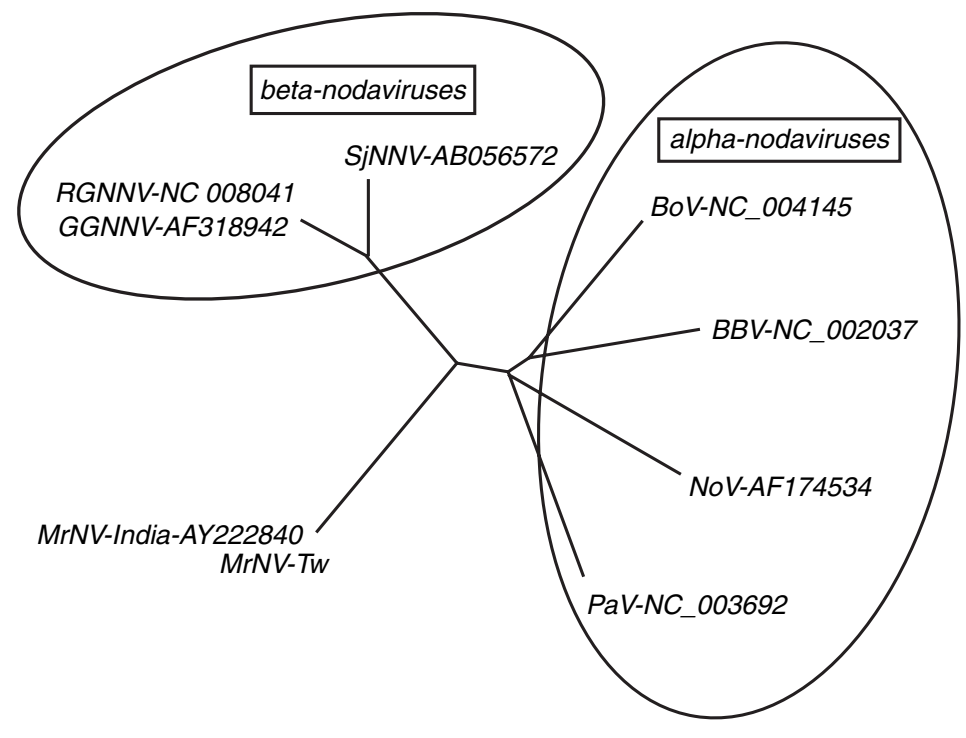

Figure 4 Phylogenetic un-rooted neighbour-joining tree deduced from analysis of nucleotide sequences of the complete gene of Macrobrachium rosenbergii nodavirus $(M r \mathrm{NV})$ capsid protein (Taiwan isolates) compared with other nodavirus isolates; Indian $M r \mathrm{NV}$ strain (AY222840), black beetle virus (BBV) (NC002037), Boolarra virus $(\mathrm{BoV})(\mathrm{NC004145)}$, greasy grouper nervous necrosis virus (GGNNV) (AF318942), Nodamura virus (NoV) (AF174534), red spotted grouper nervous necrosis virus (RGNNV) (NC008041), Pariacoto virus (PaV) (NC003692), striped jack nervous necrosis virus (SJNNV) (AB056572).
Genome-based detection methods have been developed to detect $M r \mathrm{NV}$, among which RTPCR is considered one of the most sensitive diagnostic methods in routine health monitoring (Sri Widada et al. 2003). In the present study, two primer pairs specific to $M r \mathrm{NV}$ were used; 850 and $425 \mathrm{bp}$ amplified products were obtained with primer pairs specific to RNA-1 and RNA-2, respectively, confirming that $M r \mathrm{NV}$ was associated with WTD of $M$. rosenbergii cultured in Taiwan. In addition, the striated muscle of WTD-affected prawns was shown to be positive for $M \mathrm{rNV}$ by in situ hybridization. Precipitation was only observed in the cytoplasm of necrotic muscle. The absence of any precipitate in tissues not infected by $M r \mathrm{NV}$ suggested that this DIG probe does not cross-react with prawn tissue. In situ hybridization can accurately provide the precise location of the nuclei acids present in tissue sections as a result of the highly specific interaction between the probe and target sequence of viral nuclei acids. The techniques can be used to investigate the transmission route of $M r \mathrm{NV}$ and help produce specific pathogen-free larvae of freshwater prawns in the future.

Macrobrachium rosenbergii nodavirus is classified as a member of the family Nodaviridae by its morphological and biochemical characteristics (Qian et al. 2003). Nodaviruses were first isolated from insects (Garzon \& Charpentier 1991) and recently have been found in the larvae or juveniles of some marine fish (Munday, Kwang \& Moody
2002). Because a highly conserved region was observed on the coat protein genes of fish nodaviruses, comparison with the variable region of the gene sequences could elucidate their evolutionary relationships. Based on the partial sequences of coat proteins from 25 isolates, fish nodaviruses are classified into four genotypes: barfin flounder nervous necrosis virus, tiger puffer nervous necrosis virus, SJNNV and RGNNV (Nishizawa, Furuhashi, Nagai, Nakai \& Muroga 1997). In the present study, RT-PCR amplified products of the viral capsid gene of $M r \mathrm{NV}$ were sequenced and compared using BLAST analysis with the nucleotide sequence of insect and fish nodaviruses. The results showed that the $M r \mathrm{NV}$ Taiwan isolate did not belong to any genus within the family Nodaviridae, but has more affinity with the genus Alphanodavirus than with Betanodavirus. The phylogenetic relationships between $M r \mathrm{NV}$ and other nodaviruses were in agreement with previous reports which compared the amino acid sequences deduced from the partial gene of RNA-dependent RNA polymerase (Bonami et al. 2005).

Sequence analysis of the partial genome of $M r$ NV RNA-2 demonstrated that it contained a unique open reading frame with 1116 nucleotides and encoded a structural protein with 371 amino acids. These results are similar to previous reports for an Indian isolate. The nucleotide sequence of RNA-2 of the $M r N V$ Taiwan isolate showed $97 \%$ homology with an Indian isolate by BLAST analysis. In addition, the deduced amino acid sequence of 
the $M r \mathrm{NV}$ Taiwan isolate showed similar homology. Only five deduced amino acid substitutions were observed compared with the Indian isolate. The conserved sequences indicate that $M r \mathrm{NV}$ from different geographical regions are closely related.

White tail disease has been associated with $\mathrm{MrNV}$ and its associated XSV. Although the role of the two viruses in the development of WTD is unknown, it is hypothesized that XSV represents a new species of satellite virus (Sri Widada \& Bonami 2004). Using real-time RT-PCR, these authors concluded that the higher the infection dose of $M r \mathrm{NV}$, the higher the yield of both $M r \mathrm{NV}$ and $\mathrm{XSV}$. Furthermore, the linear correlation between $M r \mathrm{NV}$ and XSV genome copies in infected prawns demonstrated that XSV is a satellite virus dependent on $M r N V$ (Zhang, Wang, Yuan, Li, Zhang, Bonami \& Shi 2006). The present study demonstrated $M r \mathrm{NV}$ infection in WTD-infected PL of freshwater prawns in Taiwan. The same specimens also showed XSV co-infection as demonstrated by RT-PCR and in situ hybridization (data not shown). The pathogenicity of $M r \mathrm{NV}$ and the associated XSV virus and their relationship to WTD merit further study.

\section{References}

Altschul S.F., Madden T.L., Schäffer A.A., Zhang J., Zhang Z., Miller W. \& Lipman D.J. (1997) Gapped BLAST and PSIBLAST: a new generation of protein database search programs. Nucleic Acids Research 25, 3389-3402.

Arcier J.M., Herman F., Lightner D.V., Redman R.M., Mari J. \& Bonami J.R. (1999) A viral disease associated with mortalities in hatchery-reared postlarvae of the giant freshwater prawn Macrobrachium rosenbergii. Diseases of Aquatic Organisms 38, 177-181.

Bell T.A. \& Lightner D.V. (1988) A Handbook of Normal Penaeid Shrimp Histology. World Aquaculture Society, Baton Rouge, LA.

Bonami J.R., Shi Z., Qian D. \& Sri Widada J. (2005) White tail disease of the giant freshwater prawn, Macrobrachium rosenbergii: separation of the associated virions and characterization of $M r \mathrm{NV}$ as a new type of nodavirus. Journal of Fish Diseases 28, 23-31.

Garzon S. \& Charpentier G. (1991) Nodaviridae. In: Atlas of Invertebrate Viruses (ed. by J.R. Adams \& J.R. Bonami), pp. 351-370. CRC Press, Boca Raton, FL.

Munday B.L., Kwang J. \& Moody N. (2002) Betanodavirus infections of teleost fish: a review. Journal of Fish Diseases 25, $127-142$.

Nishizawa T., Furuhashi M., Nagai T., Nakai T. \& Muroga K. (1997) Genomic classification of fish nodaviruses by molecular phylogenetic analysis of the coat protein gene. Applied and Environmental Microbiology 63, 1633-1636.

Qian D., Shi Z., Zhang S., Cao Z., Liu W., Li L., Xie Y., Cambournac I. \& Bonami J.R. (2003) Extra small virus-like particles (XSV) and nodavirus associated with whitish muscle disease in the giant freshwater prawn, Macrobrachium rosenbergii. Journal of Fish Diseases 26, 521-527.

Romestand B. \& Bonami J.R. (2003) A sandwich enzyme linked immunosorbent assay (S-ELISA) for detection of $\mathrm{MrNV}$ in the giant freshwater prawn, Macrobrachium rosenbergii (de Man). Journal of Fish Diseases 26, 71-75.

Sahul Hameed A.S., Yoganandhan K., Sri Widada J. \& Bonami J.R. (2004) Studies on the occurrence of Macrobrachium rosenbergii nodavirus and extra small virus-like particles associated with white tail disease of $M$. rosenbergii in India by RTPCR detection. Aquaculture 238, 127-133.

Saitou N. \& Nei M. (1987) The neighbor-joining method: a new method for reconstructing phylogenetic trees. Molecular Biology and Evolution 4, 406-425.

Shekhar M.S., Azad I.S. \& Jithendran K.P. (2006) RT-PCR and sequence analysis of Macrobrachium rosenbergii nodavirus: Indian isolate. Aquaculture 252, 128-132.

Sri Widada J. \& Bonami J.R. (2004) Characteristics of the monocistronic genome of extra small virus, a virus-like particle associated with Macrobrachium rosenbergii nodavirus: possible candidate for a new species of satellite virus. Journal of General Virology 85, 643-646.

Sri Widada J., Durand S., Cambournac I., Qian D., Shi Z., Dejonghe E., Richard V. \& Bonami J.R. (2003) Genomebased detection methods of Macrobrachium rosenbergii nodavirus, a pathogen of the giant freshwater prawn, Macrobrachium rosenbergii: dot-blot, in situ hybridization and RT-PCR. Journal of Fish Diseases 26, 583-590.

Sri Widada J., Richard V., Shi Z., Qian D. \& Bonami J.R. (2004) Dot-blot hybridization and RT-PCR detection of extra small virus (XSV) associated with white tail disease of prawn Macrobrachium rosenbergii. Diseases of Aquatic Organisms 58, 83-87.

Thompson J.D., Higgins D.G. \& Gibson T.J. (1994) clustal w: improving the sensitivity of progressive multiple sequence alignment through sequence weighting, position-specific gap penalties and weight matrix choice. Nucleic Acids Research 22, 4673-4680.

Tung C.W., Wang C.S. \& Chen S.N. (1999) Histological and electron microscopic study on Macrobrachium muscle virus (MMV) infection in the giant freshwater prawn, Macrobrachium rosenbergii (de Man), cultured in Taiwan. Journal of Fish Diseases 22, 319-323.

Wang C.S., Chang J.S., Shi H.H \& Chen S.N. (2007) RT-PCR amplification and sequence analysis of extra small virus associated with white tail disease of Macrobrachium rosenbergii (de Man) cultured in Taiwan. Journal of Fish Diseases 30, 127132.

Yoganandhan K., Sri Widada J., Bonami J.R. \& Sahul Hameed A.S. (2005) Simultaneous detection of Macrobrachium rosenbergii nodavirus and extra small virus by a single tube, one-step multiplex RT-PCR assay. Journal of Fish Diseases 28, 65-69. (c) 2008 The Authors. Journal compilation (C) 2008 Blackwell Publishing Ltd 
Yoganandhan K., Leartvibhas M., Sriwongpuk S \& Limsuwan C. (2006) White tail disease of the giant freshwater prawn Macrobrachium rosenbergii in Thailand. Diseases of Aquatic Organisms 69, 255-258.

Zhang H., Wang J., Yuan J., Li L., Zhang J., Bonami J.R. \& Shi Z. (2006) Quantitative relationship of two viruses ( $M r N V$ and
XSV) in white-tail disease of Macrobrachium rosenbergii. Diseases of Aquatic Organisms 71, 11-17.

Received: 30 November 2006

Revision received: 13 July 2007

Accepted: 2 August 2007 